\title{
Immobilization of Phenylalanine Ammonia-lyase via EDTA Based Metal Chelate Complexes - Optimization and Prospects
}

\author{
Evelin Sánta-Bell1, Norbert Krisztián Kovács ${ }^{1,2}$, Bálint Alács¹, Zsófia Molnár1,3, Gábor Hornyánszky 1,4* \\ 1 Department of Organic Chemistry and Technology, Faculty of Chemical Technology and Biotechnology, Budapest University of \\ Technology and Economics, H-1111 Budapest, Müegyetem rkp. 3., Hungary \\ 2 Fermentia Ltd, H-1045 Budapest, Berlini u. 47-49., Hungary \\ ${ }^{3}$ Institute of Enzymology, ELKH-Research Center for Natural Sciences, H-1117 Budapest, Magyar tudósok krt. 2., Hungary \\ ${ }^{4}$ SynBiocat Ltd., H-1172 Budapest, Szilasliget u. 3., Hungary \\ *Corresponding author, e-mail: hornyanszky.gabor@vbk.bme.hu
}

Received: 19 January 2021, Accepted: 01 March 2021, Published online: 27 May 2021

\begin{abstract}
Immobilized metal ion affinity chromatography principles were applied for selective immobilization of recombinant polyhistidine tag fused phenylalanine ammonia-lyase from parsley (PCPAL) on porous polymeric support with aminoalkyl moieties modified with an EDTA dianhydride (EDTADa)-derived chelator and charged with transition metal ions. Out of the five investigated metal ions - $\mathrm{Fe}^{3+}, \mathrm{Co}^{2+}$, $\mathrm{Ni}^{2+}, \mathrm{Cu}^{2+}, \mathrm{Zn}^{2+}$ - the best biocatalytic activity of PCPAL was achieved when the enzyme was immobilized on the $\mathrm{Co}^{2+}$ ion-charged support $(31.8 \pm 1.2 \mathrm{U} / \mathrm{g})$. To explore the features this PCPAL obtained by selective immobilization, the thermostability and reusability of this PAL biocatalyst were investigated. To maximize the activity of the immobilized PCPAL the surface functionalization of the aminoalkylated polymeric carrier was fine-tuned with using glycidol as a thinning group beside EDTADa. The maximal activity yield $\left(Y_{A}=103 \%\right)$ was earned when the EDTADa and glycidol were used in 1 to 24 ratio. The reversibility of the immobilization method allowed the development of a support regeneration protocol which enables easy reuse of the functionalized support in case of enzyme inactivation.
\end{abstract}

Keywords

IMAC, selective enzyme immobilization, phenylalanine ammonia-lyase

\section{Introduction}

The expansion of employing enzymes in food and pharmaceutical industry, development of novel biosensors and synthesis of small organic compounds spawned the need of creating more stable and easily recyclable biocatalysts [1-3]. Enzyme immobilization can enhance resistance against the conditions of use ( $\mathrm{pH}$, temperature, organic solvents) and give an opportunity for reuse and application in continuous flow mode [4-9]. Nowadays there are several well-known methods for enzyme immobilization: covalent immobilization [6, 7, 10-14], adsorption [15, 16], embedding in polymer [17-19] or silica-based matrices [20, 21]. New methods have emerged as well over the last decades, in which specifically tagged enzymes can be immobilized via specific interactions [22-25]. The appropriate immobilization method and a suitable carrier for it can significantly improve the properties of the biocatalyst [26-28].

In the late 1970s, Porath and coworkers discovered that histidine, cysteine and tryptophan amino acids can coordinate with transitional metal ions [29, 30]. Originally, this phenomenon called immobilized metal ion affinity chromatography (IMAC), is used consciously for protein purification [31]. Histidine tags artificially attached to the recombinant target proteins make them suitable to form stable metal-protein complexes, hence facilitating a simple and effective way for protein purification.

In addition to preparing pure enzyme solutions, the principle of IMAC can also be applied in selective enzyme immobilization. Applying this technique, immobilized biocatalyst can be produced in a one-step operation that involves the purification and the immobilization of the enzyme as well [25, 32-35]. The most used metal complexing agents in this IMAC based selective enzyme immobilization methods are the iminodiacetic acid [34-38] and nitrilotriacetic acid [32, 39-43].

The interaction between the immobilized metal ion and the protein provides a reversible immobilization. Opposed 
to multipoint covalent attachment, this approach enables more conformational changes of the enzyme which may be advantageous to achieve maximal biocatalytic activity. In case of enzyme inactivation, the reversibility of this method enables elution of the inactivated form of the immobilized enzyme from the surface and the support can be reused in a new immobilization cycle.

Phenylalanine ammonia-lyases (PALs), a member of the MIO-enzymes family, catalyzes the nonoxidative ammonia elimination reaction of L-phenylalanine in plants, fungi and bacteria [44, 45]. Nowadays the properties, structure and catalytic activity of phenylalanine ammonia-lyases (PALs) are intensively investigated because of the importance of PALs in the production of enantiomerically pure amino acids (phenylalanine and its derivatives) [45-51], and their application in the enzyme replacement therapy of phenylketonuria [52].

In this study our aim is to demonstrate the usefulness of the metal affinity-based immobilization method not on a simple monomeric but on a more demanding multimeric enzyme. Thus, phenylalanine ammonia-lyase from Petroselinum crispum (parsley) (PcPAL) having a tetrameric structure and promising biocatalytic activity has been selected as target enzyme for this study. So far mostly covalent immobilization methods [47, 48, 53-57] and encapsulation techniques [58,59] have been studied for PAL enzymes, another affinity-based method have already been described in our previous work [24].

Our major goal was to find an appropriate metal ion for the selective complexation of the PcPAL from crude lysate using EDTA dianhydride derived chelator, explore the properties of the biocatalyst and demonstrate the advantage of a reversible His-tag based immobilization.

\section{Results and discussion}

In this work, we wanted to test the activity and stability of PcPAL enzyme with an $N$-terminal His-tag [60] in its immobilized form as a metal chelate complex. To find an appropriate metal ion for the IMAC-type immobilization, the different forms of His-tagged PcPAL anchored to EDTA-based IMAC support charged with transition metal ions-iron(III), cobalt(II), nickel(II), copper(II), zinc(II)were characterized by thermal stability and reusability tests.

First, the surface of an appropriate aminoalkyl polymeric resin was modified with proper functions enabling the metal ion complexation. In the previous IMAC applications, mainly iminodiacetic acid or nitrilotriacetic acid-based functions were applied as metal-complexing agent. Iminodiacetic acid is linked to the support via epoxy groups, and nitrilotriacetic acid is usually reacted in a $\mathrm{C}-\mathrm{C}$ coupling reaction [35] at the alpha carbon or in a reaction with a lysine derivative $\left(N_{\alpha}, N_{\alpha}\right.$ bis(carboxymethyl)-L-lysine) [32, 40, 41, 43]. The disadvantage of the epoxy functionalized surface is that the remaining epoxy groups must be blocked to avoid subsequent covalent enzyme immobilization.

In this research, a commercially available polymeric resin with aminoalkyl functions at the surface was modified and applied as solid support. To create the properly modified surface capable of complexing transition metal ions, dianhydride of ethylenediaminetetraacetic acid (EDTADa) was used. After the simple reaction between an amino group and an anhydride and no blocking steps were required prior to the enzyme immobilization (Fig. 1). This type of surface modification is feasible with any other complexing agent with multiple carboxylate functions turned to anhydride(s).

\subsection{Selection of metal ions for the affinity-based support}

Three immobilization protocols differing in the washing steps and storage conditions were tested during the metal ion selection for PcPAL immobilization. In the first case (A), the biocatalysts were washed only with buffers containing $\mathrm{KCl}$ after the enzyme immobilization and stored at $4{ }^{\circ} \mathrm{C}$ under TRIS buffer (100 mM, pH 8.8). In the second case (B), a washing step with low concentration of imidazole buffer was added to the washing process. These biocatalysts were stored at $4{ }^{\circ} \mathrm{C}$ under TRIS buffer (100 mM, pH 8.8) after the immobilization as well. In the third case $(\mathrm{C})$, the previous washing protocol (B) was repeated, but after washing with imidazole buffer the biocatalysts were dried in a vacuum chamber and was also stored at $4{ }^{\circ} \mathrm{C}$. For each metal ion charged support, maximal enzyme loading was achieved for the biocatalyst. To determine their capacity the activity of supernatant was measured after the immobilization process and compared to the activity of the original PcPAL containing cell lysate.

During the PcPAL immobilization we found that the $\mathrm{Fe}^{3+}$ and $\mathrm{Cu}^{2+}$ ions leak from the polymer support (the color of supernatant turned into light orange or blue). In case of $\mathrm{Cu}^{2+}$ ion this effect is not surprising due to the known good complexing properties of this ion with amino acids.

The complexations and activity measurements were performed in three replicates. The immobilized PcPAL biocatalysts were tested in the ammonia elimination reaction from L-phenylalanine leading to trans-cinnamic acid (Fig. 2, Table 1). For reference, no significant immobilization of PcPAL was observed onto a metal ion-free support. 


\section{Surface modification}

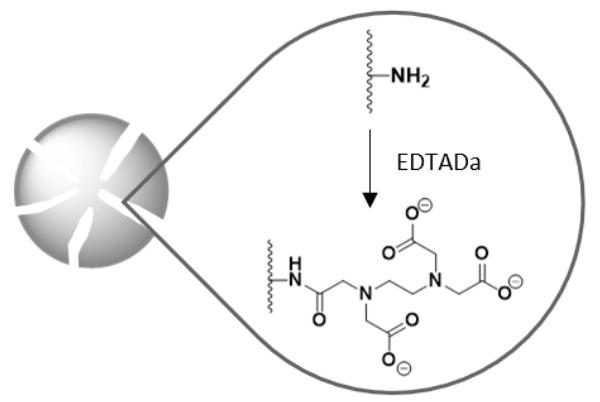

2. Metal ion complexation

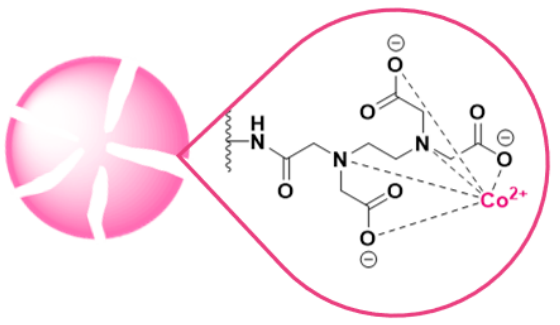

3. PCPAL immobilization

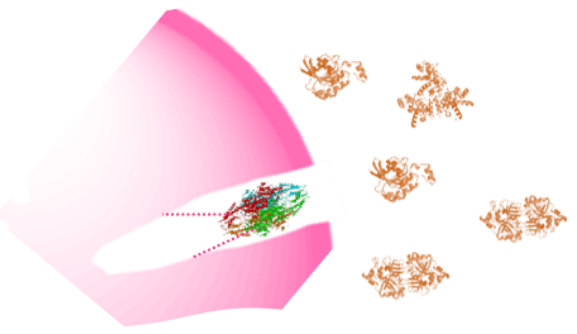

\section{Immobilized PCPAL as biocatalyst}

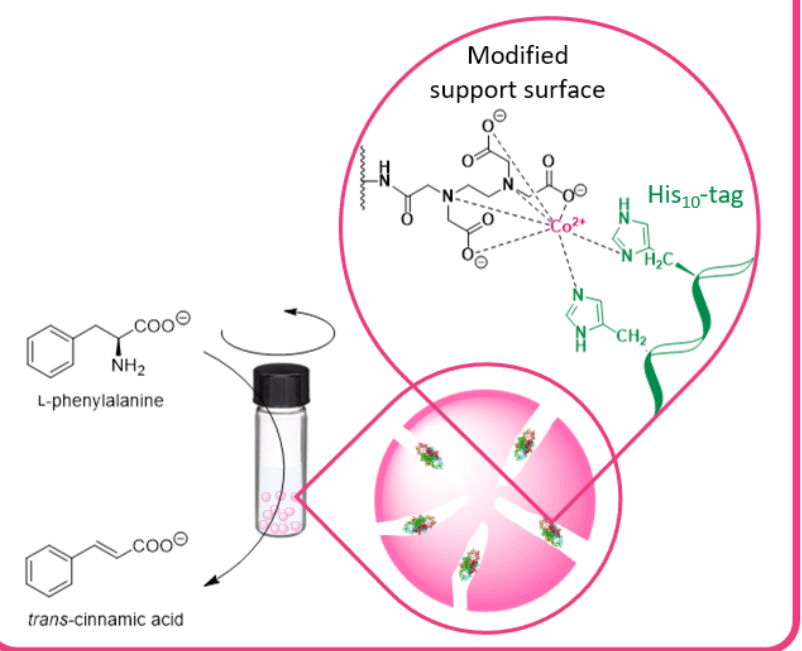

Porous polymeric support

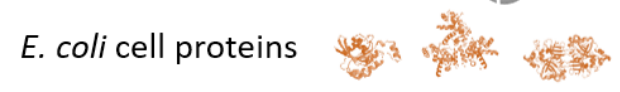

His-tagged phenylalanine ammonia-lyase

Fig. 1 Surface modification and preparation of selectively immobilized phenylalanine ammonia-lyase biocatalyst.

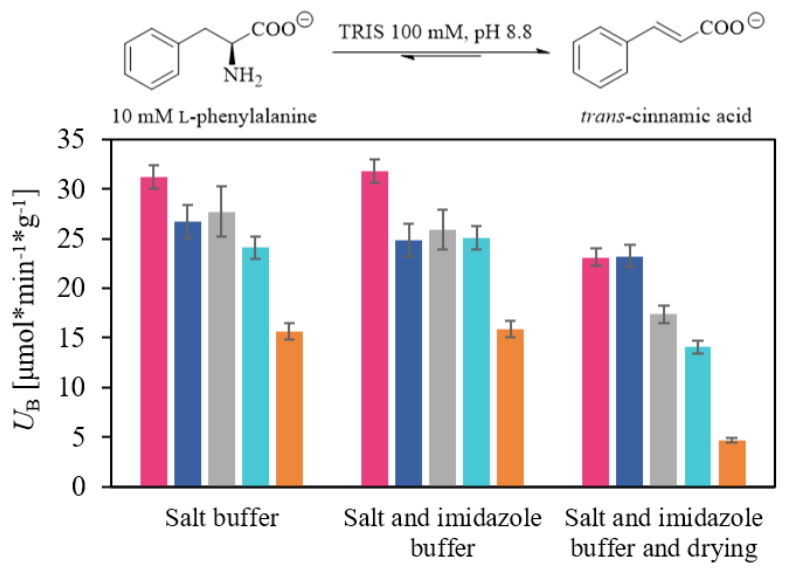

Fig. 2 Specific biocatalytic activity of immobilized PcPAL on chelating support. The complexations were performed with five different metal ions and three different washing protocols were used. Magenta: $\mathrm{Co}^{2+}$, blue: $\mathrm{Cu}^{2+}$, gray: $\mathrm{Zn}^{2+}$, turquoise: $\mathrm{Ni}^{2+}$, orange: $\mathrm{Fe}^{3+}$. The activity was determined in the ammonia elimination reaction of L-phenylalanine (Subsection 3.6).

Independently of the type of the immobilized metal ions, there was no significant difference between the two washing protocols involving no strong drying (methods A and B, Fig. 1, Table 1). In both charging ion test series applying the mild washing methods (A and $\mathrm{B}$ ), the best activities were observed on the $\mathrm{Co}^{2+}$-charged support. In case of dried biocatalysts (C), the PcPAL on support charged with $\mathrm{Co}^{2+}$ ions and $\mathrm{Cu}^{2+}$ ions were the most active, but in the latter case $\mathrm{Cu}^{2+}$ ion leakage was observed during the test reaction.

In addition to the capacity measurement after the IMACtype immobilization, the composition of the complexed or adsorbed proteins was analyzed with polyacrylamide gel electrophoresis (Fig. 3). According to the SDS-PAGE analysis, the $\mathrm{Fe}^{3+}$ ion charged support could complex the target PCPAL with good selectivity but with quite low capacity.

Using $\mathrm{Co}^{2+}$ and $\mathrm{Cu}^{2+}$ ions in the complex resulted in much better capacity (Table 1), although in the latter case the selectivity was poor due to the easy complexation of amino acid other than $\mathrm{His}$ to $\mathrm{Cu}^{2+}$ as mentioned earlier. The $\mathrm{Ni}^{2+}$ - and $\mathrm{Zn}^{2+}$-complexed polymers lacked both capacity and selectivity.

Based on the specific biocatalytic activity, capacity and selectivity results and the simplicity of use and storage, the $\mathrm{Co}^{2+}$-based, dried PcPAL biocatalyst $\left(P_{c} \mathrm{PAL}_{\mathrm{Co}(\mathrm{II}-\mathrm{C}}\right)$ was chosen to characterize further the thermostability, reusability and storage stability measurements.

\subsection{Stability tests}

The thermal behavior of $P c \mathrm{PAL}_{\mathrm{Co}(\mathrm{II})-\mathrm{C}}$ was measured in 2 hours test reactions between $20^{\circ} \mathrm{C}$ and $80{ }^{\circ} \mathrm{C}$ (Fig. 4). 
Table 1 Capacity, specific biocatalytic activity and activity yield of immobilized $P c$ PAL on chelating support. The complexations were performed with five different metal ions and three different washing protocols were used. The activity was determined as described at Subsection 3.6.

\begin{tabular}{|c|c|c|c|c|c|c|c|}
\hline \multirow{3}{*}{ Metal ion } & \multirow{3}{*}{$\begin{array}{c}\text { Capacity } \\
\mu \mathrm{g} \text { protein to } \\
5 \mathrm{mg} \text { support }\end{array}$} & \multicolumn{2}{|c|}{ Washing protocol A } & \multicolumn{2}{|c|}{ Washing protocol B } & \multicolumn{2}{|c|}{ Washing protocol C } \\
\hline & & $U_{\mathrm{B}}$ & $Y_{\mathrm{A}}$ & $U_{\mathrm{B}}$ & $Y_{\mathrm{A}}$ & $U_{\mathrm{B}}$ & $Y_{\mathrm{A}}$ \\
\hline & & $\mu \mathrm{mol} \min ^{-1} \mathrm{~g}^{-1}$ & $\%$ & $\mu \mathrm{mol} \min ^{-1} \mathrm{~g}^{-1}$ & $\%$ & $\mu \mathrm{mol} \min ^{-1} \mathrm{~g}^{-1}$ & $\%$ \\
\hline $\mathrm{Co}^{2+}$ & $771 \pm 54$ & $31.2 \pm 1.2$ & 103 & $31.8 \pm 1.2$ & 104 & $23.1 \pm 0.8$ & 76 \\
\hline $\mathrm{Cu}^{2+}$ & $656 \pm 49$ & $26.7 \pm 1.7$ & 103 & $24.8 \pm 1.7$ & 96 & $23.2 \pm 1.1$ & 90 \\
\hline $\mathrm{Zn}^{2+}$ & $589 \pm 119$ & $27.7 \pm 2.6$ & 119 & $25.9 \pm 2.2$ & 111 & $17.3 \pm 0.9$ & 75 \\
\hline $\mathrm{Ni}^{2+}$ & $588 \pm 28$ & $24.1 \pm 1.1$ & 104 & $25.1 \pm 1.2$ & 108 & $14.1 \pm 0.7$ & 61 \\
\hline $\mathrm{Fe}^{3+}$ & $505 \pm 25$ & $15.7 \pm 0.8$ & 78 & $15.8 \pm 0.8$ & 79 & $4.7 \pm 0.2$ & 23 \\
\hline
\end{tabular}

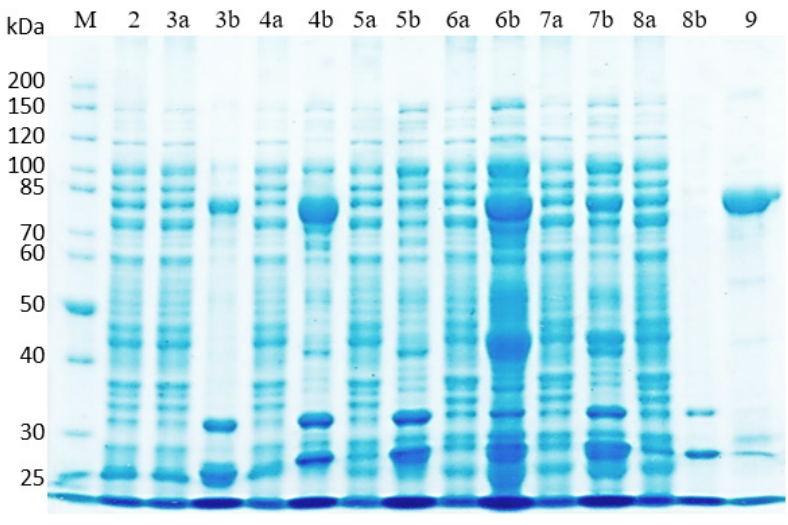

Fig. 3 SDS-PAGE analysis of the immobilized $P c$ PAL biocatalysts. M: Protein ladder, 2: crude lysate of PcPAL expressing E. coli, 3-7: PcPAL immobilized on IMAC support charged with various metal ions (3: $\mathrm{Fe}^{3+}, 4: \mathrm{Co}^{2+}, 5: \mathrm{Ni}^{2+}, 6: \mathrm{Cu}^{2+}, 7: \mathrm{Zn}^{2+}, 8:$ metal free; Series a: supernatant after complexation, series b: polymer after complexation), 9: solution of PcPAL ( $81 \mathrm{kDa})$ purified on NiNTA.

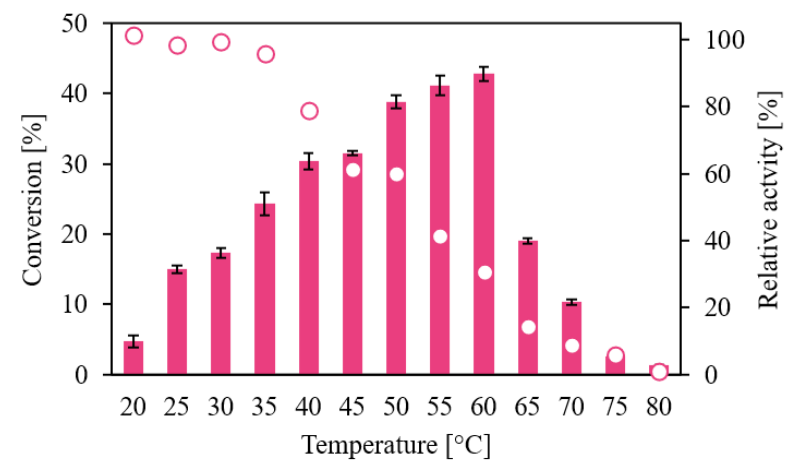

Fig. 4 Effect of temperature on productivity of $P c \mathrm{PAL}_{\mathrm{Co}(\mathrm{II})-\mathrm{C}}$ (columns: conversion in $2 \mathrm{~h}$ reactions), and the residual activity of of $P c \mathrm{PAL}_{\mathrm{Co}(\mathrm{III}) \mathrm{C}^{-}}$ after the $2 \mathrm{~h}$ use at different temperatures (dots: relative activity [\%] = activity at $30^{\circ} \mathrm{C}$ after using the catalyst at a given temperature / activity at $30^{\circ} \mathrm{C}$ at first using $\times 100$ ).

The productivity increased up to $60^{\circ} \mathrm{C}$ and then a significant loss of enzyme activity was observed.

After the thermal productivity test, the remaining activity of the $P c \mathrm{PAL}_{\mathrm{Co}(\mathrm{II})-\mathrm{C}}$ was also determined at $30^{\circ} \mathrm{C}$ in activity assay to determine the permanent activity loss after the 2 hours reaction at a given temperature.

These experiments clearly showed that longer incubation at $40{ }^{\circ} \mathrm{C}$ or higher temperature caused permanent decrease or complete loss of biocatalytic activity. If temperatures above $65^{\circ} \mathrm{C}$ were used, a significant decrease in activity was observed even in the first reaction. Previous measurements confirms that at $65{ }^{\circ} \mathrm{C}$ protein unfolding already begins, leading to complete denaturation of $P c$ PAL enzyme [48].

To test the $P c \mathrm{PAL}_{\mathrm{Co}(\mathrm{II})-\mathrm{C}}$ operational stability at ambient temperature, the biocatalyst was applied in five consecutive ammonia elimination reactions from L-phenylalanine ( $2 \mathrm{~h}$ at $30^{\circ} \mathrm{C}$, each, Fig. 5). Analyses of small aliquots from the reaction mixtures by SDS-PAGE indicated no detectable enzyme leakage in course of the reusability study.

Between the reaction cycles, the biocatalysts were washed with buffer and were dried out in vacuum chamber to measure the amount of the biocatalyst precisely in the next cycle. Although the activity decreased from cycle to cycle, after the fourth cycle $58 \%$ of the initial enzyme activity could be retained.

To test the long-term stability, the dried biocatalysts were stored at three different temperature $\left(-20^{\circ} \mathrm{C}, 4^{\circ} \mathrm{C}\right.$ and $\left.27^{\circ} \mathrm{C}\right)$

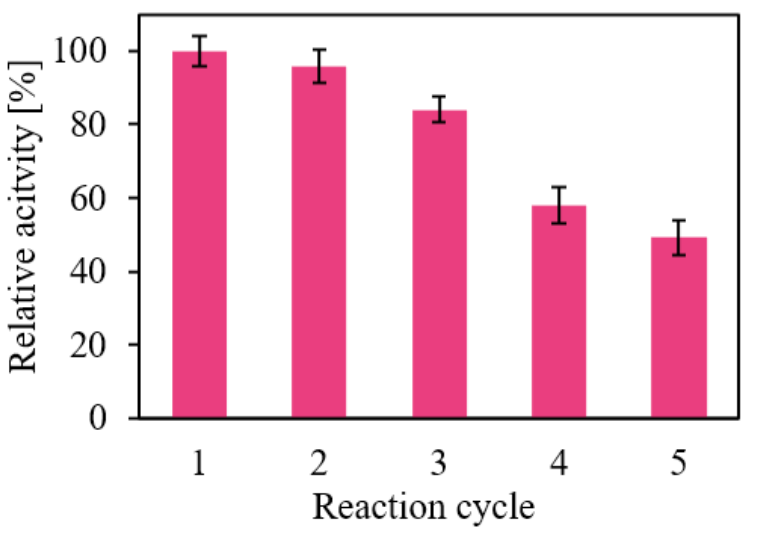

Fig. 5 Operational stability of immobilized $P c \mathrm{PAL}_{\mathrm{Co}(\mathrm{II})-\mathrm{C}}$. Relative activity $[\%]=$ activity in given cycle $/$ activity in first cycle $\times 100$. 
and the residual activities were tested after 30,60 and 90 days (Table 2) which is a quiet long interval time compared to previous studies for PAL catalysts [57, 59]. After one month the biocatalysts stored at $-20{ }^{\circ} \mathrm{C}$ and $4{ }^{\circ} \mathrm{C}$ retained more than $80 \%$ of their activity. The residual activity of biocatalyst stored at room temperature after 30 days was a little bit weaker, but it was still comparable to the storage stability of PAL catalysts in the literature [53, 59, 61].

\subsection{Regeneration of the support}

The advantage of enzyme immobilization via affinity binding to metal complexes is the easy reusability of the support after the enzyme losing its activity. To demonstrate this, we optimized a washing protocol to elute the (exhausted) enzyme from the support and reuse the regenerated IMAC support in a further enzyme immobilization cycle. During the optimization of the support regeneration protocol, the supports and washing fractions were tested with SDS-PAGE.

First, the $P c \mathrm{PAL}_{\mathrm{Co}(\mathrm{II})-\mathrm{C}}$ biocatalyst was washed with imidazole solution (500 $\mathrm{mM}$ and $1 \mathrm{M})$. Surprisingly, even after being washed three times with imidazole solution (1 M), detectable amount of enzyme remained on the support. Furthermore, several chelating agents were tested for elution of the enzyme, such as ethylenediamine $(5 \%$ solution in TRIS buffer, $100 \mathrm{mM}, \mathrm{pH} \mathrm{8.8),} \mathrm{diethylenetri-}$ amine (5\% solution in TRIS buffer, $100 \mathrm{mM}, \mathrm{pH} 8.8$ ), EDTA (at $100 \mathrm{mM}$ and $200 \mathrm{mM}, \mathrm{pH}$ 8.0) and diethylenediaminepentaacetic acid (at $100 \mathrm{mM}$ and $200 \mathrm{mM}, \mathrm{pH}$ 8.0). Even after elution of the immobilized $\mathrm{Co}^{2+}$ ions from the support, a small amount of enzyme remained on its surface. This phenomenon can be explained with a strong ionic adsorption of the enzyme without metal chelate. To elute the remaining enzyme, a two-step elution was used: at first it was washed with diethlyenetriamine solution (three times) and after that the remaining proteins were eluted with $\mathrm{NaCl}$ (360 $\mathrm{g} \mathrm{L}^{-1}$, three times). During this washing, $\mathrm{Co}^{2+}$ ions and enzyme could be detected in the elution fractions, but not on the support after washing.

After the full removal of the enzymes from the previous immobilization, the support was washed with distilled

Table 2 Long-term stability of PcPAL biocatalysts at three different storage temperature

\begin{tabular}{lccc}
\hline \multirow{2}{*}{$\begin{array}{l}\text { Storage } \\
\text { temperature }\end{array}$} & after 30 days & after 60 days & after 90 days \\
\hline$-20^{\circ} \mathrm{C}$ & 84 & 78 & 69 \\
$4{ }^{\circ} \mathrm{C}$ & 81 & 71 & 61 \\
$25{ }^{\circ} \mathrm{C}$ & 65 & 57 & 48 \\
\hline
\end{tabular}

water and then complexed again with $\mathrm{Co}^{2+}$ ions. The metal complexed support was used in a new enzyme immobilization cycle. The freshly made and the reused supports were compared in the test reactions as before. Only a very slight difference was observed between the reused and the newly functionalized support (Table 3 ).

These experiments clearly demonstrated the reusability of the regenerated support after removal of the exhausted enzyme as another advantage of this immobilization technique besides the usual reuse of the biocatalyst. Thus, the tedious production of the IMAC carrier does not need to be repeated for every immobilization process.

\subsection{Fine-tuning of the support's surface}

Application of inert groups not involved in the complex formation during the surface modification can affect the surface density of the functional groups, the microenvironment around the immobilized enzyme and also stabilizing secondary interactions may occur thereby influencing significantly the specific biocatalytic activity [62-64].

Importantly, these groups are applicable to modulate the surface density of the functional points for enzyme immobilization and thus, the amount of immobilized enzyme in a controllable way. By decreasing the surface density of the functional points - in this case the chelating groups - the amount of the immobilized enzyme can be set properly. There is an optimal space requirement for the individual enzyme molecules. When the binding functions are too dense, the tight packing of the enzyme complexes can result in crowding which may impede conformational changes required for catalytic activity. At the optimal density, packing allows sufficient conformational mobility but there remains no empty surface without enzyme covering. When attachment points are too rare, the low surface coverage results in a poor specific activity.

In addition to modulate the surface density of the functional groups, the inert groups also affect the microenvironment, most importantly the hydrophilic or hydrophobic properties of the surface. The surface properties influence the enzyme adsorption and in case of a porous support have large effect on the diffusion properties also.

Table 3 Comparison of the $P c \mathrm{PAL}_{\mathrm{Co}(\mathrm{II})-\mathrm{C}}$ biocatalysts on freshly prepared and regenerated supports.

\begin{tabular}{|c|c|c|}
\hline & Support type & $\begin{array}{c}\boldsymbol{U}_{\mathbf{B}}^{{ }^{\mathrm{a}}} \\
{\left[\mu \mathrm{mol} \mathrm{min} \mathrm{m}^{-1} \mathrm{~g}^{-1}\right]}\end{array}$ \\
\hline 1 & Freshly prepared support & $23.1 \pm 0.8^{\mathrm{a}}$ \\
\hline 2 & Reused support after regeneration process & $22.8 \pm 1.0^{\mathrm{a}}$ \\
\hline
\end{tabular}


To modulate the density of the chelating groups on the aminoalkyl functionalized support, glycidol was used in addition to EDTA dianhydride (EDTADa) in different ratios. In addition to adjust the surface density of chelating groups, glycidol results in formation of hydrophilic diol functions on the surface [65]. Beside the creation of IMAC support solely with EDTADa functionalization, modified IMAC supports were also prepared with eight different EDTADa / glycidol molar ratio from 1:1 to 1:36. There was no difference in the specific biocatalytic activity, however, as the ratio increased the amount of immobilized enzyme was decreased (Table 4). These results are understandable in the view of the large surface area covered by a single PcPAL enzyme (being almost a spheroid with $\sim 20 \AA$ length and $\sim 10 \AA$ diameter, see the PDB structure of $P c$ PAL with a substrate analogue: $6 \mathrm{HQF}$ ).

\section{Experimental}

\subsection{Chemicals and biological reagents}

EDTA (ethylenediaminetetraacetic acid, $99.5 \%$ ), glycidol (96 \%), TRIS [tris(hydroxymethyl)aminomethane] (99.8\%), potassium chloride (99\%), nickel(II) acetate tetrahydrate (98\%), cobalt(II) acetate tetrahydrate (98\%) and copper(II) acetate monohydrate (98\%) were purchased from Sigma-Aldrich (Saint Louis, MO, USA). Iron(III) chloride hexahydrate (97\%), zinc(II) acetate dihydrate (97 \%), HEPES [4-(2-hydroxyethyl)-1-piperazineethanesulfonic acid] (99\%) and L-phenylalanine (99\%) were purchased from Alfa Aesar Europe (Karlsruhe, Germany).

Acetic anhydride and all solvents were purchased from Merck KGaA (Darmstadt, Germany) and used without further purification except for dimethylformamide

Table 4 Effect of glycidol - EDTADa ratio to the during IMAC support formation on the specific biocatalytic activity and activity yield of the resulting $P c \mathrm{PAL}_{\mathrm{Co}(\mathrm{II})-\mathrm{c}}$.

\begin{tabular}{|c|c|c|c|}
\hline & $\begin{array}{l}\text { Quantity of glycidol to } \\
\text { one unit of EDTADa }\end{array}$ & $\begin{array}{c}\text { Specific biocatalytic } \\
\text { activity }\left(U_{\mathrm{B}}\right)^{\mathrm{a}} \\
{\left[\mu \mathrm{mol} \mathrm{min} \mathrm{m}^{-1}\right]}\end{array}$ & $\begin{array}{c}\text { Activity } \\
\text { yield }\left(Y_{\mathrm{A}}\right)^{\mathrm{a}} \\
{[\%]} \\
\end{array}$ \\
\hline 1 & 0 & $23.0 \pm 0.5$ & 76 \\
\hline 2 & 1 & $23.2 \pm 1.0$ & 74 \\
\hline 3 & 3 & $23.3 \pm 1.6$ & 75 \\
\hline 4 & 6 & $21.9 \pm 0.7$ & 83 \\
\hline 5 & 9 & $23.2 \pm 1.1$ & 89 \\
\hline 6 & 12 & $23.3 \pm 1.3$ & 77 \\
\hline 7 & 18 & $22.6 \pm 0.8$ & 81 \\
\hline 8 & 24 & $23.3 \pm 1.0$ & 103 \\
\hline 9 & 36 & $21.7 \pm 1.6$ & 95 \\
\hline
\end{tabular}

a Specific biocatalytic activity and activity yield values were calculated as described in Subsection 3.6. which was dried over $4 \AA$ molecular sieve. Patosolv ( $~ 85-$ $90 \% \mathrm{EtOH}+10-15 \%$ 2-propanol) was obtained from Molar Chemicals Ltd. (Budapest, Hungary).

Hexylamine-functionalized methacrylic polymer resin (ReliZyme ${ }^{\mathrm{TM}}$ HA 403/S) with a 150-300 $\mu \mathrm{m}$ particle size, and 400-600 ̊ pore size was product of Resindion S.r.l. (Rome, Italy).

Expression of recombinant phenylalanine ammonia-lyase from parsley (Petroselinum crispum) carrying $N$-terminal His -tag in E. coli Rosetta $^{\mathrm{TM}}$ host was carried out at Fermentia Ltd. according to the method already described by Dima et al. [60].

All the other chemicals used for sodium dodecyl sulfate polyacrylamide gel electrophoresis (SDS-PAGE) were purchased from Sigma-Aldrich (Saint Louis, MO, USA) (ammonium persulfate, glycerol, sodium dodecyl sulfate) or Merck KGaA (Darmstadt, Germany) (glycine, $40 \%$ acrylamide/bis 37.5:1 solution, DL-dithiothreitol, bromophenol blue). Protein Ladder (10 to $200 \mathrm{kDa}$ ) was product of ThermoFisher Scientific (Waltham, Massachusetts, USA), and ProSieve Blue protein staining solution was the product of Lonza (Basel, Switzerland). Brine (360 $\mathrm{g} \mathrm{L}^{-1}$ $\mathrm{NaCl}$ in deionized water) was prepared in our lab.

The UV absorbance and kinetic measurements were carried out Genesys 2 type spectrophotometer (Thermo Fisher Scientific Inc., Waltham, MA, USA) and semi-micro PMMA cuvettes were used.

SDS-PAGE analysis was carried out on MiniPROTEAN Tetra cell electrophoresis chamber (Bio-Rad Laboratories Inc, Hercules, CA, USA) with an Enduro Power Supplies thickness of $0.75 \mathrm{~mm}$.

For the drying processes VDL 23 vacuum drying chamber (Binder GmbH, Tuttlingen, Germany) was used.

The centrifugation separation steps were carried out in a Hermle Z 400K universal laboratory centrifuge (Hermle LaborTechnik GmbH, Wehingen, Germany).

\subsection{Preparation of ethylenediaminetetraacetic dianhydride (EDTADa)}

EDTA $(100 \mathrm{~g}, 0.34 \mathrm{~mol})$ and pyridine $(170 \mathrm{~mL})$ were mixed in a $500 \mathrm{~mL}$ four necked flask under argon. The suspension was stirred for $1 \mathrm{~h}$ at $65{ }^{\circ} \mathrm{C}$ followed by dropwise addition of acetic anhydride $(130 \mathrm{~mL}, 1.34 \mathrm{~mol})$ to the solution. The reaction mixture was kept at $65^{\circ} \mathrm{C}$ for $16 \mathrm{~h}$. The resulting product was filtered off, washed with pyridine and diethyl ether, subsequently, and dried under vacuum. The white solid product was stored in a sealed container under argon at $4{ }^{\circ} \mathrm{C}$. 


\subsection{Surface modification of the hexylamine- functionalized polymer resins}

The original water content ( $65 \%$ ) of the macroporous hexylamine-functionalized resins was removed before further use. In a glass filter wet resins $(50 \mathrm{~g})$ were suspended and washed with Patosolv $(2 \times 100 \mathrm{~mL})$ and hexane $(100 \mathrm{~mL})$, including filtration between the washing steps. After the final filtration, the resins were dried at room temperature in a vacuum drying chamber until the vacuum level dropped below 10 mbar, resulting in $17.4 \mathrm{~g}$ of dry resins.

In a dried $20 \mathrm{~mL}$ screw cap vial dried resins $(1.0 \mathrm{~g})$ were suspended in $\mathrm{N}, \mathrm{N}$-dimethylformamide $(10 \mathrm{~mL})$. To the suspension of resins the proper amounts of EDTADa, glycidol and $N, N$-diethyl- $N$-isopropylamine (two equivalents to the EDTADa) were added [the total amounts of EDTADa and glycidol were two equivalents related to the amino group content of the polymer $\left(1750 \mu \mathrm{mol} \mathrm{g} \mathrm{g}^{-1}\right)$ but in different molar ratios (EDTADa-glycidol: 1-0; 1-1; 1-3; 1-6; 1-12; 1-18; $1-24 ; 1-36)]$. The resulted mixture was shaken at $450 \mathrm{rpm}$ for $24 \mathrm{~h}$ at $60^{\circ} \mathrm{C}$, then distilled water $(100 \mu \mathrm{L})$ was added and the mixture was shaken further for $1 \mathrm{~h}$ at $60^{\circ} \mathrm{C}$. After the hydrolytic quenching, the resins were filtered and washed with acetonitrile $(3 \times 20 \mathrm{~mL})$ and 2-propanol $(20 \mathrm{~mL})$, dried in a vacuum drying chamber at room temperature for $5 \mathrm{~h}$ (until the vacuum level dropped below 10 mbar).

\subsection{Charging of the chelator-functionalized resins with metal ions}

Charging of the chelator-functionalized resins with metal ion was performed in $15 \mathrm{~mL}$ screw cap vials. The modified IMAC resins (100 mg) were suspended in the solution of the corresponding metal salt $\left[5 \mathrm{~mL}, 50 \mathrm{mmol} \mathrm{L}^{-1}\right.$ of $\mathrm{Ni}(\mathrm{OAc})_{2} \times 4 \mathrm{H}_{2} \mathrm{O}, \mathrm{Co}(\mathrm{OAc})_{2} \times 4 \mathrm{H}_{2} \mathrm{O}, \mathrm{Cu}(\mathrm{OAc})_{2} \times \mathrm{H}_{2} \mathrm{O}$, $\mathrm{FeCl}_{3} \times 6 \mathrm{H}_{2} \mathrm{O}$, or $\left.\mathrm{Zn}(\mathrm{OAc})_{2} \times 2 \mathrm{H}_{2} \mathrm{O}\right]$. The mixture was shaken at $450 \mathrm{rpm}$ for 30 minutes at room temperature, then the metal-charged resins were filtered off and washed with distilled water $(3 \times 10 \mathrm{~mL})$ and 2-propanol $(10 \mathrm{~mL})$, dried in vacuum drying chamber at room temperature for $5 \mathrm{~h}$ (until the vacuum level dropped below $10 \mathrm{mbar}$ ).

\subsection{Immobilization of phenylalanine ammonia-lyase from parsley (washing protocol $\mathrm{C}$ )}

To the metal ion-complexed resins $(20 \mathrm{mg})$ was added the lysate of $E$. coli cells $(30 \mathrm{mg} / \mathrm{mL}$ total protein in lysis buffer: $50 \mathrm{mmol} \mathrm{L}{ }^{-1}$; TRIS $150 \mathrm{mmol} \mathrm{L}^{-1}, \mathrm{pH}$ 8.0) expressing Histagged PcPAL (4 mL, PcPAL concentration $1.4 \mathrm{mg} / \mathrm{mL}$, sufficient for maximal enzyme loading). The suspension was shaken at $450 \mathrm{rpm}$ for $30 \mathrm{~min}$ at room temperature to bind the His-tagged enzyme. The nonspecifically adsorbed host proteins were eluted with sequential addition of the following solutions ( $1 \mathrm{~mL}$ each): low salt buffer $\left(30 \mathrm{mmol} \mathrm{L}^{-1} \mathrm{KCl}\right.$; 50 mmol L-1 HEPES, pH 7.5); high salt buffer (300 $\mathrm{mmol} \mathrm{L}^{-1}$ $\mathrm{KCl}, 50 \mathrm{mmol} \mathrm{L}^{-1} \mathrm{HEPES}$, $\mathrm{pH} 7.5$ ); low concentration imidazole buffer $\left(25 \mathrm{mmol} \mathrm{L}^{-1}\right.$ imidazole, $30 \mathrm{mmol} \mathrm{L}^{-1} \mathrm{KCl}$, $50 \mathrm{mmol} \mathrm{L}^{-1}$ HEPES, pH 7.5). The immobilized biocatalysts were washed with deionized water $(3 \times 1 \mathrm{~mL})$ and dried in a vacuum drying chamber at room temperature for $2 \mathrm{~h}$ (until the vacuum level dropped below 10 mbar).

A tenfold scaling-up of the immobilization was accomplished with the EDTADa-Co(II) modified resin using the same immobilization method as described above.

\subsection{Activity measurements with the PcPAL biocatalysts}

To a solution of L-phenylalanine $\left(2 \mathrm{~mL}, 10 \mathrm{mmol} \mathrm{L}^{-1}\right.$ in $100 \mathrm{mmol} \mathrm{L}^{-1}$ TRIS buffer; $\mathrm{pH}$ 8.8) was added the immobilized PcPAL (5 mg) and the mixture was shaken at $750 \mathrm{rpm}$ at $30{ }^{\circ} \mathrm{C}$. After $0.5,1$ and $2 \mathrm{~h}$, samples $(50 \mu \mathrm{L})$ were taken and diluted with distilled water to a final volume of $1 \mathrm{~mL}$. Conversion of L-phenylalanine to trans-cinnamic acid was determined by UV-spectroscopy from the absorption change of cinnamic acid at $290 \mathrm{~nm}\left(\varepsilon_{290}=9.530 \mathrm{~L} \mathrm{~cm}^{-1} \mathrm{~mol}^{-1}\right)$ by using the Lambert-Beer equation.

To monitor the efficiency of the enzyme immobilization, the PcPAL activity of the crude cell lysate was measured before and after the immobilization process. An aliquot of the centrifuged crude cell lysate $(20 \mu \mathrm{L})$ was added to L-phenylalanine solution $\left(1 \mathrm{~mL}, 10 \mathrm{mmol} \mathrm{L}^{-1}\right.$ in TRIS buffer $\left.\left(100 \mathrm{mmol} \mathrm{L}^{-1} ; \mathrm{pH} 8.8\right)\right)$ at $30^{\circ} \mathrm{C}$ and the absorbance change was detected at $290 \mathrm{~nm}$ for $2 \mathrm{~min}$.

To characterize the productivity of the immobilized PcPAL, the specific biocatalytic activity was calculated using Eq. (1):

$U_{\mathrm{B}}=n_{\mathrm{P}} /\left(t \times m_{\mathrm{B}}\right)$,

where $n_{\mathrm{P}}(\mu \mathrm{mol})$ is the amount of the product, $t$ [min] is the reaction time and $m_{\mathrm{B}}(\mathrm{g})$ is the mass of the applied biocatalyst). Activity yield was calculated using Eq. (2)

$Y_{\mathrm{A}}=100 \times U_{\mathrm{E}}($ cat $) / U_{\mathrm{E}}(\mathrm{im})$,

where $U_{\mathrm{E}}$ (cat) is the $U_{\mathrm{E}}$ of the biocatalyst and $U_{\mathrm{E}}(\mathrm{im})$ is the difference of the $U_{\mathrm{E}}$ of the lysate between the beginning and the end of the immobilization process). The specific enzyme activity was calculated using Eq. (3):

$U_{\mathrm{E}}=U_{\mathrm{B}} \times\left(m_{\mathrm{B}} / m_{\mathrm{E}}\right)$,

where $m_{\mathrm{E}}(\mathrm{g})$ is the mass of the PcPAL in the applied biocatalyst; in case of the cell lysate $m_{\mathrm{E}}(\mathrm{g})$ was calculated from the determined PcPAL concentration of the lysate). 
To determine $m_{\mathrm{E}}$, a small amount of the lysate was purified on Ni-sepharose 6 Fast Flow affinity chromatography medium (Cytiva, Marlborough, MA, USA) according to the specification of the manufacturer.

\subsection{Tests for thermal effects on productivity and stability of the PcPAL biocatalyst}

The $P C \mathrm{PAL}_{\mathrm{Co}(\mathrm{II})-\mathrm{C}}$ biocatalyst $(5 \mathrm{mg})$ was added to a solution of L-phenylalanine $\left(2 \mathrm{~mL}, 10 \mathrm{mmol} \mathrm{L}^{-1}\right.$ in TRIS buffer (100 mmol L $\left.{ }^{-1}, \mathrm{pH} 8.8\right)$ ) and the mixture was shaken at $750 \mathrm{rpm}$ at different temperatures between $20^{\circ} \mathrm{C}$ and $80^{\circ} \mathrm{C}$ with $5{ }^{\circ} \mathrm{C}$ increments. After 2 hours reaction time, the conversion and biocatalytic activity $\left(U_{\mathrm{B}}{ }^{\mathrm{T}}\right.$, where $\mathrm{T}$ is the reaction temperature) was calculated based on UV-spectroscopic method described at Subsection 3.6. Then the biocatalyst was washed with TRIS buffer (100 $\mathrm{mmol} \mathrm{L}^{-1}$; pH 8.8) three times. The biocatalyst was separated with centrifugation (3500 rpm, $2 \mathrm{~min}$ ) in each washing steps.

To measure the thermal stability, fresh solution of L-phenylalanine $\left(2 \mathrm{~mL}, 10 \mathrm{mmol} \mathrm{L}^{-1}\right.$ in TRIS buffer (100 mmol L $\left.\mathrm{m}^{-1} \mathrm{pH} 8.8\right)$ ) was added to the washed biocatalyst and the mixture was shaken at $750 \mathrm{rpm}$ at $30^{\circ} \mathrm{C}$. The conversion and biocatalytic activity $\left(U_{\mathrm{B}}^{\mathrm{T}-30^{\circ} \mathrm{C}}\right.$, where $\mathrm{T}$ is the reaction temperature at the first reaction) were measured after $2 \mathrm{~h}$ reaction. The residual activity for every temperature was calculated from the activity in the second reaction at $30{ }^{\circ} \mathrm{C}$ and the activity of the first use at $30{ }^{\circ} \mathrm{C}$ :

$U_{\mathrm{B}, \mathrm{rem}}=\left(U_{\mathrm{B}}^{\mathrm{T}-30^{\circ} \mathrm{C}} / U_{\mathrm{B}}^{30^{\circ} \mathrm{C}}\right) \times 100$.

\subsection{Reusability tests with the PcPAL biocatalyst}

The $P c \mathrm{PAL}_{\mathrm{Co}(\mathrm{II})-\mathrm{C}}$ biocatalyst $(25 \mathrm{mg})$ was added to a solution of L-phenylalanine ( $2 \mathrm{~mL} / 5 \mathrm{mg}$ biocatalyst, $10 \mathrm{mmol} \mathrm{L}^{-1}$ in $100 \mathrm{mmol} \mathrm{L}^{-1}$ TRIS buffer; $\mathrm{pH} \mathrm{8.8)} \mathrm{and}$ the mixture was shaken at $750 \mathrm{rpm}$ at $30{ }^{\circ} \mathrm{C}$. After $2 \mathrm{~h}$ reaction, the biocatalyst was separated and washed with TRIS buffer ( $\left.5 \mathrm{~mL}, 100 \mathrm{mmol} \mathrm{L}^{-1}, \mathrm{pH} 8.8\right)$ three times and with deionized water $(5 \mathrm{~mL})$. In each washing steps the biocatalyst was separated with centrifugation $(3500 \mathrm{rpm}$, $2 \mathrm{~min}$ ). After washing, the biocatalyst was dried in a vacuum drying chamber at room temperature for $2 \mathrm{~h}$ (until the vacuum level dropped below 10 mbar). The mass of the dried biocatalyst was measured and the same substrate solution - biocatalyst ratio was used in the second reaction cycle. The reactions were performed five times in this way.

\subsection{Regeneration of the chelator-functionalized support} The $P c \mathrm{PAL}_{\mathrm{Co}(\mathrm{II})-\mathrm{C}}$ biocatalyst $(50 \mathrm{mg})$ was washed three times with diethlyenetriamine solution $(10 \mathrm{ml}, 5 \%$ solution in TRIS buffer (100 mM, pH 8.8); each), three times with brine $(10 \mathrm{~mL}$; each) and finally with deionized water $(3 \times 10 \mathrm{~mL})$. The biocatalysts were separated with centrifugation (3500 rpm, $2 \mathrm{~min}$ ) in each washing steps. After that the support was used in a second metal ion complexation and enzyme immobilization step according to Subsections 3.4 and 3.5.

\section{Conclusion}

In this study a facile way of selective enzyme immobilization is presented that allows a simple support recycling. This method is based on the IMAC principle, thus provides a one-step purification and immobilization process for polyhistidine-tagged recombinant enzymes. The usefulness of this method was demonstrated with immobilization of His-tagged phenylalanine ammonia-lyase from parsley ( $P c$ PAL) on an EDTA-functionalized macroporous polymer resin charged with various metal ions.

The immobilization efficiency and specific biocatalytic activity of PcPAL on the EDTA-based IMAC resins proved to be the better with cobalt(II) ion $(23.1 \mathrm{U} / \mathrm{g})$ then with nickel(II) ion (14.1 U/g), which is widespread in commercial protein purification protocols. Additionally, the cobalt(II)-containing PcPAL biocatalyst performed the best capacity (771 $\mu \mathrm{g} / 5 \mathrm{mg}$ support) with negligible enzyme leakage. Additionally, this immobilization method enables a facile recycling of the valuable IMAC carrier by elution of the exhausted PcPAL when needed.

The surface modification is easy to implement with any amino groups containing support and can be simply finetuned by "diluting" the chelating functions on the surface by various inert groups. Setting a proper density of the chelating functions by "dilution" with diol functions deriving from glycidol increased the activity yield of PCPAL immobilization without decreasing the specific biocatalytic activity.

\section{Acknowledgement}

The research reported in this paper and carried out at BME has been supported by the NRDI Fund [project (TKP2020 IES, Grant No. BME-IE-BIO) based on the charter of bolster issued by the NRDI Office under the auspices of the Ministry for Innovation and Technology; and project (SNN-125637)]. 


\section{References}

[1] Wu, S., Snajdrova, R., Moore, J. C., Baldenius, K., Bornscheuer, U. T. "Biocatalysis: Enzymatic Synthesis for Industrial Applications", Angewandte Chemie: International Edition, 60(1), pp. 88-119, 2021. https://doi.org/10.1002/anie.202006648

[2] DiCosimo, R., McAuliffe, J., Poulose, A. J., Bohlmann, G. "Industrial use of immobilized enzymes", Chemical Society Reviews, 42(15), pp. 6437-6474, 2013.

https://doi.org/10.1039/c3cs35506c

[3] Eş, I., Vieira, J. D. G., Amaral, A. C. "Principles, techniques, and applications of biocatalyst immobilization for industrial application", Applied Microbiology and Biotechnology, 99(5), pp. 2065-2082, 2015.

https://doi.org/10.1007/s00253-015-6390-y

[4] Boros, Z., Weiser, D., Márkus, M., Abaháziová, E., Magyar, Á., Tomin, A., Koczka, B., Kovács, P., Poppe, L. "Hydrophobic adsorption and covalent immobilization of Candida antarctica lipase B on mixed-function-grafted silica gel supports for continuous-flow biotransformations", Process Biochemistry, 48(7), pp. 1039-1047, 2013.

https://doi.org/10.1016/j.procbio.2013.05.002

[5] Romero-Fernández, M., Paradisi, F. "Protein immobilization technology for flow biocatalysis", Current Opinion in Chemical Biology, 55, pp. 1-8, 2020.

https://doi.org/10.1016/j.cbpa.2019.11.008

[6] Abaházi, E., Lestál, D., Boros, Z., Poppe, L. "Tailoring the Spacer Arm for Covalent Immobilization of Candida antarctica Lipase B-Thermal Stabilization by Bisepoxide-Activated Aminoalkyl Resins in Continuous-Flow Reactors", Molecules, 21(6), Article number: 767, 2016.

https://doi.org/10.3390/molecules21060767

[7] Abaházi, E., Sátorhelyi, P., Erdélyi, B., Vértessy, B. G., Land, H., Paizs, C., Berglund, P., Poppe, L. "Covalently immobilized Trp60Cys mutant of $\omega$-transaminase from Chromobacterium violaceum for kinetic resolution of racemic amines in batch and continuous-flow modes", Biochemical Engineering Journal, 132, pp. 270-278, 2018.

https://doi.org/10.1016/j.bej.2018.01.022

[8] Yu, D., Chen, K., Liu, J., Pan, Z., Jiang, L., Wang, L., Elfalleh, W. "Application of magnetic immobilized papain on passivated rice bran lipase", International Journal of Biological Macromolecules, 157, pp. 51-59, 2020.

https://doi.org/10.1016/j.ijbiomac.2020.04.132

[9] Manoel, E. A., Pinto, M., Dos Santos, J. C. S., Tacias-Pascacio, V. G., Freire, D. M. G., Pinto, J. C., Fernandez-Lafuente, R. "Design of a core-shell support to improve lipase features by immobilization", RSC Advances, 6(67), pp. 62814-62824, 2016.

https://doi.org/10.1039/c6ra13350a

[10] Nagy, B., Galla, Z., Bencze, L. C., Toșa, M. I., Paizs, C., Forró, E., Fülöp, F. "Covalently Immobilized Lipases are Efficient Stereoselective Catalysts for the Kinetic Resolution of rac-(5Phenylfuran-2-yl)- $\beta$-alanine Ethyl Ester Hydrochlorides", European Journal of Organic Chemistry, 2017(20), pp. 2878-2882, 2017. https://oi.org/10.1002/ejoc.201700174
[11] Oláh, M., Suba, S., Boros, Z., Kovács, P., Gosselin, M., Gaudreault, C., Hornyánszky, G. "Lipase B from Candida antarctica Immobilized on Epoxy-functionalized Hollow Silica Microspheres: Efficient Biocatalysts for Enantiomer Selective Acylation of Alcohols and Amines", Periodica Polytechnica Chemical Engineering, 62(4), pp. 519-532, 2018, https://doi.org/10.3311/PPch.12517

[12] Nagy, F., Szabó, K., Bugovics, P., Hornyánszky, G. "Bisepoxideactivated Hollow Silica Microspheres for Covalent Immobilization of Lipase from Burkholderia cepacia", Periodica Polytechnica Chemical Engineering, 63(3), pp. 414-424, 2019. https://doi.org/10.3311/PPch.12665

[13] Nagy, F., Gyujto, I., Tasnádi, G., Barna, B., Balogh-Weiser, D., Faber, K., Poppe, L., Hall, M. "Design and application of a bi-functional redox biocatalyst through covalent co-immobilization of ene-reductase and glucose dehydrogenase", Journal of Biotechnology, 323, pp. 246-253, 2020. https://doi.org/10.1016/j.jbiotec.2020.08.005

[14] Mehde, A. A., Mehdi, W. A., Severgün, O., Çakar, S., Özacar, M. "Lipase-based on starch material as a development matrix with magnetite cross-linked enzyme aggregates and its application", International Journal of Biological Macromolecules, 120, pp. 1533-1543, 2018.

https://doi.org/10.1016/j.ijbiomac.2018.09.141

[15] Pinto Brito, M. J., Bauer, L. C., Flores Santos, M. P., Santos, L. S., Ferreira Bonomo, R. C., da Costa Ilhéu Fontan, R., Veloso, C. M. "Lipase immobilization on activated and functionalized carbon for the aroma ester synthesis", Microporous and Mesoporous Materials, 309, Article number: 110576, 2020. https://doi.org/10.1016/j.micromeso.2020.110576

[16] Hegyesi, N., Hodosi, E., Polyák, P., Faludi, G., Balogh-Weiser, D., Pukánszky, B. "Controlled degradation of poly-e-caprolactone for resorbable scaffolds", Colloids and Surfaces B: Biointerfaces, 186, Article number: 110678, 2020.

https://doi.org/10.1016/j.colsurfb.2019.110678

[17] Krisch, E., Balogh-Weiser, D., Klimkó, J., Gyarmati, B., Laszló, K., Poppe, L., Szilágyi, A. "Composite beads of silica gel, alginate and poly(aspartic acid) for the immobilization of a lipase enzyme", eXPRESS Polymer Letters, 13(6), pp. 512-523, 2019. https://doi.org/10.3144/expresspolymlett.2019.43

[18] Sóti, P. L., Weiser, D., Vigh, T., Nagy, Z. K., Poppe, L., Marosi, G. "Electrospun polylactic acid and polyvinyl alcohol fibers as efficient and stable nanomaterials for immobilization of lipases", Bioprocess and Biosystems Engineering, 39(3), pp. 449-459, 2016. https://doi.org/10.1007/s00449-015-1528-y

[19] Rashid, R., Anwar, Z., Zafar, M., Rashid, T., Butt, I. "Chitosanalginate immobilized lipase based catalytic constructs: Development, characterization and potential applications", International Journal of Biological Macromolecules, 119, pp. 992-1001, 2018. https://doi.org/10.1016/j.ijbiomac.2018.07.192

[20] Moisă, M. E., Spelmezan, C. G., Paul, C., Bartha-Vári, J. H., Bencze, L. C., Irimie, F. D., Paizs, C., Péter, F., Toşa, M. I. "Tailored sol-gel immobilized lipase preparates for the enzymatic kinetic resolution of heteroaromatic alcohols in batch and continuous flow systems", RSC Advances, 7(83), pp. 52977-52987, 2017. https://doi.org/10.1039/c7ra10157k 
[21] Weiser, D., Nagy, F., Bánóczi, G., Oláh, M., Farkas, A., Szilágyi, A., László, K., Gellért, Á., Marosi, G., Kemény, S., Poppe, L. "Immobilization engineering - How to design advanced sol-gel systems for biocatalysis?", Green Chemistry, 19(16), pp. 3927-3937, 2017.

https://doi.org/10.1039/C7GC00896A

[22] Mateo, C., Fernández-Lorente, G., Cortés, E., Garcia, J. L., Fernández-Lafuente, R., Guisan, J. M. "One-step purification, covalent immobilization, and additional stabilization of poly-His-tagged proteins using novel heterofunctional chelate-epoxy supports", Biotechnology and Bioengineering, 76(3), pp. 269-276, 2001. https://doi.org/10.1002/bit.10019

[23] Nagy, F., Tasnádi, G., Balogh-Weiser, D., Bell, E., Hall, M., Faber, K., Poppe, L. "Smart Nanoparticles for Selective Immobilization of Acid Phosphatases", ChemCatChem, 10(16), pp. 3490-3499, 2018.

https://doi.org/10.1002/cctc.201800405

[24] Sánta-Bell, E., Molnár, Z., Varga, A., Nagy, F., Hornyánszky, G., Paizs, C., Balogh-Weiser, D., Poppe, L. ""Fishing and Hunting"Selective Immobilization of a Recombinant Phenylalanine Ammonia-Lyase from Fermentation Media", Molecules, 24(22), Article number: 4146, 2019.

https://doi.org/10.3390/molecules24224146

[25] Cassimjee, K. E., Federsel, H. J. "CHAPTER 13. EziG: A Universal Platform for Enzyme Immobilisation", In: de Gonzalo, G., de María, P. D. (eds.) Biocatalysis: An Industrial Perspective, Royal Society of Chemistry, Cambridge, UK, 2017, pp. 345-362.

[26] dos Santos, J. C. S., Barbosa, O., Ortiz, C., Berenguer-Murcia, A., Rodrigues, R. C., Fernandez-Lafuente, R. "Importance of the Support Properties for Immobilization or Purification of Enzymes", ChemCatChem, 7(16), pp. 2413-2432, 2015.

https://doi.org/10.1002/cctc.201500310

[27] Aggarwal, S., Chakravarty, A., Ikram, S. "A comprehensive review on incredible renewable carriers as promising platforms for enzyme immobilization \& thereof strategies", International Journal of Biological Macromolecules, 167, pp. 962-986, 2021. https://doi.org/10.1016/j.ijbiomac.2020.11.052

[28] Chakraborty, S., Rusli, H., Nath, A., Sikder, J., Bhattacharjee, C., Curcio, S., Drioli, E. "Immobilized biocatalytic process development and potential application in membrane separation: A review", Critical Reviews in Biotechnology, 36(1), pp. 43-58, 2016. https://doi.org/10.3109/07388551.2014.923373

[29] Porath, J., Carlsson, J., Olsson, I., Belfrage, G. "Metal chelate affinity chromatography, a new approach to protein fractionation", Nature, 258(5536), pp. 598-599, 1975. https://doi.org/10.1038/258598a0

[30] Porath, J., Olin, B. "Immobilized metal affinity adsorption and immobilized metal affinity chromatography of biomaterials. Serum protein affinities for gel-immobilized iron and nickel ions", Biochemistry, 22(7), pp. 1621-1630, 1983. https://doi.org/10.1021/bi00276a015

[31] Knecht, S., Ricklin, D., Eberle, A. N., Ernst, B. "Oligohistags: mechanisms of binding to $\mathrm{Ni}^{2+}$-NTA surfaces", Journal of Molecular Recognition, 22(4), pp. 270-279, 2009.

https://doi.org/10.1002/jmr.941
[32] Vahidi, A. K., Yang, Y., Ngo, T. P. N., Li, Z. "Simple and Efficient Immobilization of Extracellular His-Tagged Enzyme Directly from Cell Culture Supernatant As Active and Recyclable Nanobiocatalyst: High-Performance Production of Biodiesel from Waste Grease", ACS Catalysis, 5(6), pp. 3157-3161, 2015. https://doi.org/10.1021/acscatal.5b00550

[33] Engelmark Cassimjee, K., Kadow, M., Wikmark, Y., Svedendahl Humble, M., Rothstein, M. L., Rothstein, D. M., Bäckvall, J. E. "A general protein purification and immobilization method on controlled porosity glass: biocatalytic applications", Chemical Communications, 50(65), pp. 9134-9137, 2014. https://doi.org/10.1039/C4CC02605E

[34] Pessela, B. C. C., Mateo, C., Filho, M., Carrascosa, A., FernándezLafuente, R., Guisan, J. M. "Selective adsorption of large proteins on highly activated IMAC supports in the presence of high imidazole concentrations: Purification, reversible immobilization and stabilization of thermophilic $\alpha$ - and $\beta$-galactosidases", Enzyme and Microbial Technology, 40(2), pp. 242-248, 2007. https://doi.org/10.1016/j.enzmictec.2006.04.019

[35] Lai, W. J., Lin, S. C. "Hydroxyethyl cellulose-grafted loofa spongebased metal affinity adsorbents for protein purification and enzyme immobilization", Process Biochemistry, 74, pp. 141-147, 2018. https://doi.org/10.1016/j.procbio.2018.08.024

[36] Zhu, Q., Zhuang, W., Niu, H., Ge, L., Villacorta Hernandez, B., Wu, J., Wang, K., Liu, D., Chen, Y., Zhu, C., Ying, H. "Affinity induced immobilization of adenylate cyclase from the crude cell lysate for ATP conversion", Colloids and Surfaces B: Biointerfaces, 164, pp. 155-164, 2018.

https://doi.org/10.1016/j.colsurfb.2018.01.033

[37] Ko, Y. M., Chen, C. I., Lin, C. C., Kan, S. C., Zang, C. Z., Yeh, C. W., Chang, W. F., Shieh, C. J., Liu, Y. C. "Enhanced d-hydantoinase activity performance via immobilized cobalt ion affinity membrane and its kinetic study", Biochemical Engineering Journal, 79, pp. 200-205, 2013. https://doi.org/10.1016/j.bej.2013.08.003

[38] Ko, Y. M., Chen, C. I., Shieh, C. J., Liu, Y. C. "Simultaneous purification and immobilization of d-hydantoinase on the immobilized metal affinity membrane via coordination bonds", Biochemical Engineering Journal, 61, pp. 20-27, 2012.

https://doi.org/10.1016/j.bej.2011.11.013

[39] Vahidi, A. K., Wang, Z., Li, Z. "Facile Synthesis of S-Substituted L-Cysteines with Nano-sized Immobilized O-Acetylserine Sulfhydrylase", ChemCatChem, 10(17), pp. 3671-3674, 2018. https://doi.org/10.1002/cctc.201800577

[40] Cao, G., Gao, J., Zhou, L., Huang, Z., He, Y., Zhu, M., Jiang, Y. "Fabrication of $\mathrm{Ni}^{2+}$-nitrilotriacetic acid functionalized magnetic mesoporous silica nanoflowers for one pot purification and immobilization of His-tagged $\omega$-transaminase", Biochemical Engineering Journal, 128, pp. 116-125, 2017. https://doi.org/10.1016/j.bej.2017.09.019

[41] Zhou, L., Li, J., Gao, J., Liu, H., Xue, S., Ma, L., Cao, G., Huang, Z., Jiang, Y. "Facile Oriented Immobilization and Purification of His-Tagged Organophosphohydrolase on Viruslike Mesoporous Silica Nanoparticles for Organophosphate Bioremediation", ACS Sustainable Chemistry \& Engineering, 6(10), pp. 13588-13598, 2018.

https://doi.org/10.1021/acssuschemeng.8b04018 
[42] Kulsharova, G., Dimov, N., Marques, M. P. C., Szita, N., Baganz, F. "Simplified immobilisation method for histidine-tagged enzymes in poly(methyl methacrylate) microfluidic devices", New Biotechnology, 47, pp. 31-38, 2018. https://doi.org/10.1016/j.nbt.2017.12.004

[43] Wang, L., Wei, L., Chen, Y., Jiang, R. "Specific and reversible immobilization of NADH oxidase on functionalized carbon nanotubes", Journal of Biotechnology, 150(1), pp. 57-63, 2010. https://doi.org/10.1016/j.jbiotec.2010.07.005

[44] Kovács, K., Bánóczi, G., Varga, A., Szabó, I., Holczinger, A., Hornyánszky, G., Zagyva, I., Paizs, C., Vértessy, B. G., Poppe, L. "Expression and Properties of the Highly Alkalophilic Phenylalanine Ammonia-Lyase of Thermophilic Rubrobacter xylanophilus", PLoS ONE, 9(1), Article number: e85943, 2014. https://doi.org/10.1371/journal.pone.0085943

[45] Poppe, L., Retey, J. "Properties and Synthetic Applications of Ammonia-Lyases", Current Organic Chemistry, 7(13), pp. 1297-1315, 2003. https://doi.org/10.2174/1385272033486440

[46] Bencze, L. C., Filip, A., Bánóczi, G., Toşa, M. I., Irimie, F. D., Gellért, Á., Poppe, L., Paizs, C. "Expanding the substrate scope of phenylalanine ammonia-lyase from: Petroselinum crispum towards styrylalanines", Organic \& Biomolecular Chemistry, 15(17), pp. 3717-3727, 2017. https://doi.org/10.1039/c7ob00562h

[47] Weiser, D., Bencze, L. C., Bánóczi, G., Ender, F., Kiss, R., Kókai, E., Szilágyi, A., Vértessy, B. G., Farkas, Ö., Paizs, C., Poppe, L. "Phenylalanine Ammonia-Lyase-Catalyzed Deamination of an Acyclic Amino Acid: Enzyme Mechanistic Studies Aided by a Novel Microreactor Filled with Magnetic Nanoparticles", ChemBioChem, 16(16), pp. 2283-2288, 2015. https://doi.org/10.1002/cbic.201500444

[48] Bartha-Vári, J. H., Toşa, M. I., Irimie, F. D., Weiser, D., Boros, Z., Vértessy, B. G., Paizs, C., Poppe, L. "Immobilization of Phenylalanine Ammonia-Lyase on Single-Walled Carbon Nanotubes for Stereoselective Biotransformations in Batch and Continuous-Flow Modes", ChemCatChem, 7(7), pp. 1122-1128, 2015.

https://doi.org/10.1002/cctc.201402894

[49] Paizs, C., Katona, A., Rétey, J. "The Interaction of HeteroarylAcrylates and Alanines with Phenylalanine Ammonia-Lyase from Parsley", Chemistry: A European Journal, 12(10), pp. 2739-2744, 2006.

https://doi.org/10.1002/chem.200501034

[50] Weiser, D., Varga, A., Kovács, K., Nagy, F., Szilágyi, A., Vértessy, B. G., Paizs, C., Poppe, L. "Bisepoxide Cross-Linked Enzyme Aggregates-New Immobilized Biocatalysts for Selective Biotransformations", ChemCatChem, 6(5), pp. 1463-1469, 2014. https://doi.org/10.1002/cctc.201300806

[51] Cui, J. D., Qiu, J. Q., Fan, X. W., Jia, S. R., Tan, Z. L. "Biotechnological production and applications of microbial phenylalanine ammonia lyase: A recent review", Critical Reviews in Biotechnology, 34(3), pp. 258-268, 2014. https://doi.org/10.3109/07388551.2013.791660
[52] Hydery, T., Coppenrath, V. A. "A Comprehensive Review of Pegvaliase, an Enzyme Substitution Therapy for the Treatment of Phenylketonuria", Drug Target Insights, 13(1), pp. 1-8, 2019. https://doi.org/10.1177/1177392819857089

[53] Cui, J. D., Sun, L. M., Li, L. L. "A Simple Technique of Preparing Stable CLEAs of Phenylalanine Ammonia Lyase Using Co-aggregation with Starch and Bovine Serum Albumin", Applied Biochemistry and Biotechnology, 170(8), pp. 1827-1837, 2013. https://doi.org/10.1007/s12010-013-0317-9

[54] Cui, J. D., Li, L. L., Zhao, Y. M. "Simple Technique for Preparing Stable and Recyclable Cross-Linked Enzyme Aggregates with Crude-Pored Microspherical Silica Core", Industrial \& Engineering Chemistry Research, 53(42), pp. 16176-16182, 2014. https://doi.org/10.1021/ie5021206

[55] Cui, J., Tan, Z., Han, P., Zhong, C., Jia, S. "Enzyme Shielding in a Large Mesoporous Hollow Silica Shell for Improved Recycling and Stability Based on $\mathrm{CaCO}_{3}$ Microtemplates and Biomimetic Silicification", 65(19), pp. 3883-3890, 2017. https://doi.org/10.1021/acs.jafc.7b00672

[56] Cui, J., Zhao, Y., Tan, Z., Zhong, C., Han, P., Jia, S. "Mesoporous phenylalanine ammonia lyase microspheres with improved stability through calcium carbonate templating", International Journal of Biological Macromolecules, 98, pp. 887-896, 2017. https://doi.org/10.1016/j.ijbiomac.2017.02.059

[57] Cui, J. D., Cui, L. L., Zhang, S. P., Zhang, Y. F., Su, Z. G., Ma, G. H. "Hybrid Magnetic Cross-Linked Enzyme Aggregates of Phenylalanine Ammonia Lyase from Rhodotorula glutinis", PLoS ONE, 9(5), Article number: e97221, 2014. https://doi.org/10.1371/journal.pone.0097221

[58] Cui, J., Zhao, Y., Feng, Y., Lin, T., Zhong, C., Tan, Z., Jia, S. "Encapsulation of Spherical Cross-Linked Phenylalanine Ammonia Lyase Aggregates in Mesoporous Biosilica", 65(3), pp. 618-625, 2017. https://doi.org/10.1021/acs.jafc.6b05003

[59] Cui, J., Liang, L., Han, C., Liu, R. L. "Stabilization of Phenylalanine Ammonia Lyase from Rhodotorula glutinis by Encapsulation in Polyethyleneimine-Mediated Biomimetic Silica", Applied Biochemistry and Biotechnology, 176(4), pp. 999-1011, 2015. https://doi.org/10.1007/s12010-015-1624-0

[60] Dima, N. A., Filip, A., Bencze, L. C., Oláh, M., Sátorhelyi, P., Vértessy, B. G., Poppe, L., Paizs, C. "Expression and Purification of Recombinant Phenylalanine Ammonia-Lyase from Petroselinum crispum", Studia Universitatis Babes-Bolyai Chemia, 61(2), pp. 21-34, 2016.

[61] Cui, J., Jia, S., Liang, L., Zhao, Y., Feng, Y. "Mesoporous CLEAssilica composite microparticles with high activity and enhanced stability", Scientific Reports, 5(1), Article number: 14203, 2015. https://doi.org/10.1038/srep14203

[62] Fernandez-Lopez, L., Rueda, N., Bartolome-Cabrero, R., Rodriguez, M. D., Albuquerque, T. L., dos Santos, J. C. S., Barbosa, O., Fernandez-Lafuente, R. "Improved immobilization and stabilization of lipase from Rhizomисor miehei on octyl-glyoxyl agarose beads by using $\mathrm{CaCl}_{2}$ ", Process Biochemistry, 51(1), pp. 48-52, 2016. https://doi.org/10.1016/j.procbio.2015.11.015 
[63] Rueda, N., Albuquerque, T. L., Bartolome-Cabrero, R., FernandezLopez, L., Torres, R., Ortiz, C., Dos Santos, J. C. S., Barbosa, O., Fernandez-Lafuente, R. "Reversible Immobilization of Lipases on Heterofunctional Octyl-Amino Agarose Beads Prevents Enzyme Desorption", Molecules, 21(5), Article number: 646, 2016. https://doi.org/10.3390/molecules21050646

[64] Arana-Peña, S., Rios, N. S., Mendez-Sanchez, C., Lokha, Y., Carballares, D., Gonçalves, L. R. B., Fernandez-Lafuente, R. "Coimmobilization of different lipases: Simple layer by layer enzyme spatial ordering", International Journal of Biological Macromolecules, 145, pp. 856-864, 2020.

https://doi.org/10.1016/j.ijbiomac.2019.10.087
[65] Wilms, D., Stiriba, S. E., Frey, H. "Hyperbranched Polyglycerols: From the Controlled Synthesis of Biocompatible Polyether Polyols to Multipurpose Applications", Accounts of Chemical Research, 43(1), pp. 129-141, 2010. https://doi.org/10.1021/ar900158p 